\title{
Predicting Soil Productivity Resulted from Organic Matter Addition by Using Neural Networks
}

\author{
Diia S.M. Boulos ${ }^{1}$
}

\begin{abstract}
Artificial neural networks (ANN) model is used for predicting some soil physical properties [soil bulk density (Bd), available water (AW), infiltration rate (I)], soil spinach productivity (Pro) and water use efficiency (WUE) under three different types of organic matter [Town refuse (TR), Farmyard manure (FYM) and Compost (COM)] with three rates [10, 15 and 20 ton/fed] for each treatment. Multilayer feedforward ANN with 8 neurons in input layer, 10 and 20 neurons for first and second hidden layers respectively and 5 neurons in output layer was trained using a backpropagation learning algorithm. The ANN model was trained with data collected from previous literatures (668 observations for training and 223 observations for testing). The model inputs were [Sand $(\mathrm{S})$, Silt $(\mathrm{Si})$, Clay $(\mathrm{C})$, Town refuse (TR), Farmyard manure (FYM), Compost (COM), Electrical conductivity of irrigation water (EC) and Irrigation applied water (IR)]. The model outputs were [soil bulk density (Bd), available water (AW), infiltration rate (I), soil spinach productivity (Pro) and water use efficiency (WUE)]. Verification of the ANN model in prediction was done using field experimental data which carried out in El Sadat City (Data that ANN model has never seen before). Root mean square error (RMSE) and correlation coefficient $\left(R^{2}\right)$ were used to evaluate the ANN model. Validation and testing for the ANN model were done after careful and extensive training. The RMSE between measured and predicted values for soil bulk density (Bd), available water (AW), infiltration rate (I), soil spinach productivity (Pro) and water use efficiency (WUE) were $0.00909 \mathrm{Mg} / \mathrm{m}^{3}, 0.10528 \%, 0.23878 \mathrm{~mm} / \mathrm{h}$, $14.28973 \mathrm{~kg} / \mathrm{fed}$ and $0.26762 \mathrm{~kg} / \mathrm{m}^{3}$. While the $R^{2}$ were equal to $0.99955,0.99947,0.99902,0.99998$ and 0.96883 respectively. The high $R^{2}$ for output parameters recall indicated for excellent prediction of the ANN model for the data has never seen before.
\end{abstract}

Keywords: neural networks, soil physical properties, soil spinach productivity, water use efficiency

\section{INTRODUCTION}

Artificial neural network (ANN) is basically parallel computational model comprised of densely interconnected adaptive processing units with simulation of knowledge acquisition and organizational skills of human brain. ANN model is made up of multiple highly interconnected processing units named neurons. Being inspired by the natural neuron, an ANN receives inputs which will then be multiplied by the weights (refer to strength of the input signals), followed by computation the output. A very important characteristics of ANN includes that it can learn from the experience (experimental data) and is capable of generalization according to the knowledge that has been gained. ANN has the capability of correlating large and complex data sets without any prior knowledge of the relationship between them. It has become powerful tools for modeling a system that had incomplete or a little understanding regarding its governing law (Aru and Okpara, 2018). The strengths of ANN are that it possesses the ability to learn through the means of a set of training data, capability of generalization and association of data as well the fault tolerance in the sense of handling noise and incomplete information. Also, ANN consists the feature of parallelism which enables computations of multiple neurons simultaneously. ANN is often designed using multilayer feedforward (MLF) back propagation algorithm. MLF network, or commonly known as multilayer perceptron, is one of the most popular neural networks used in the present. In general, MLF network contains an input layer, single or multiple hidden layers and an output layer. To define a MLF network, it is a network whereby the neuron in one layer is connected to the neuron of the subsequent layer, towards the direction of output layer. Typically, the layers are entirely connected in the sense of all neurons at each layer are connected with all neurons at next layer as shown in Fig. (1) (Abdullah and Tiong, 2008).

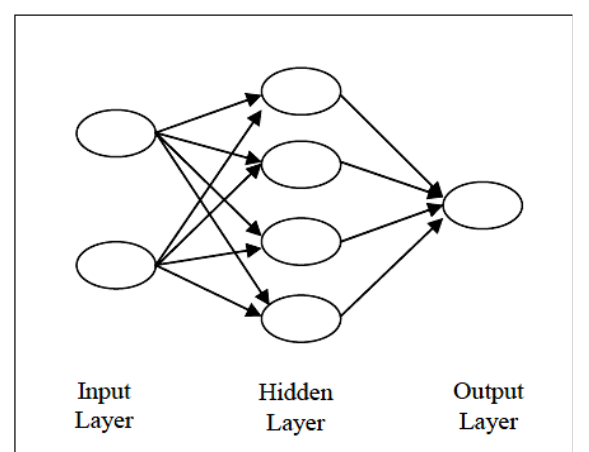

Fig. 1. Multilayer feedforward network structure

Sorour, (2006) stated that an ANN similar estimates dry matter loses and storage time of stored wheat under

DOI: 10.21608/ASEJAIQJSAE.2020.123803

${ }^{1}$ Soil Chemistry and Physics Department, Desert Research Center, Cairo, Egypt.

Received October 15, 2020, Accepted November 11, 2020 
different treatments well compared to measured values. (El Awady et al., 2003) developed an ANN to study the relative of variables affecting chisel plows performance. They reported that correlation coefficients $\left(\mathrm{R}^{2}\right)$ were over 0.90 during testing process and the width of plow was the major variable affecting draft, unit draft and energy requirements. (Aboukarima et al., 2004) predicted unit draft of tillage machine using statistical and ANN models. The ANN was a MLF network with 11 input and 1 output neurons. The input variables were chisel plow, moldboard plow, disc plow, soil texture, plowing depth, plow width, forward speed, moisture content, soil bulk density, rated tractor power, and plow passes. The output predicted the unit draft of tillage implement. The standard deviations of the errors were $9.38,6.57$ and $8.45 \mathrm{kN} / \mathrm{m}^{2}$ for moldboard, chisel and disc plows respectively. Also the $\mathrm{R}^{2}$ between the measured and predicted values were 0.95 for both the ANN and statistical analyses. The test of hypothesis using correlation coefficient and root mean square error indicated that the neural network predicts chisel plow draft with reasonable accuracy (Aboukarima and Saad, 2006). (Aboukarima, 2007) obtained data for plows in different soil characteristic, width of plow and some operational parameters with the help of ANN model. The variables were depth of plowing, power tractor, forward speed, width of plow, soil texture and water content. The $\mathrm{R}^{2}$ were 93\%. (Akbarzadehe et al., 2009) used alternative methods of ANN for predicting water runoff and particles splash in soils treated with synthetic geotextiles and bare soils. It was found that the ANN had better accuracy than regression analyses for prediction of runoff and splash. (Gholami et al., 2018) found that the ANN can predicted soil erosion with an acceptable level (RMSE $\left.=0.04, \mathrm{R}^{2}=0.94\right)$. (Warmling et al. 2019) developed an ANN model to predict field capacity (FC), wilting point (WP) and available water (AW) the results between the measured and predicted values had RMSE of $0.01,0.03$ and $0.03 \mathrm{~m}^{3} / \mathrm{m}^{3}$ and $\mathrm{R}^{2}$ were $0.99,0.92$ and 0.83 for $\mathrm{FC}, \mathrm{WP}$ and $\mathrm{AW}$, respectively.

This study aims to achieve the following objectives:

1-Construct the optimal structure of an ANN to predict some soil physical properties [soil bulk density $(\mathrm{Bd})$, available water $(\mathrm{AW})$, infiltration rate $(\mathrm{I})]$ soil productivity and water use efficiency under three different types of organic matter [town refuse (TR), farmyard manure (FYM) and compost (COM)] with three rates [10, 15 and 20 ton/fed] for each treatment.

2-Verification of the ANN model in prediction using field experimental data (Data that an ANN model has never seen before) which carried out in El Sadat City.

\section{MATERIALS AND METHODS}

\section{Field experimental}

A field experiment was conducted on sandy soil at Sadat City, Menoufia Governorate in a private farm. Seeds of spinach (Spinacia oleracea L.) were sown on $19^{\text {th }}$ October in winter season 2019 under drip irrigation system. The recommended doses of NPK mineral fertilizers were as follows phosphorus as $200 \mathrm{~kg} / \mathrm{fed} \mathrm{of}$ calcium superphosphate $\left(\begin{array}{lll}15.5 \% & \mathrm{P}_{2} \mathrm{O}_{5}\end{array}\right)$ which added during soil preparation, potassium as $70 \mathrm{~kg} / \mathrm{fed} \mathrm{of}$ potassium sulphate $\left(48-50 \% \quad \mathrm{~K}_{2} \mathrm{O}\right)$ were added three weeks after seeding, whereas nitrogen as $250 \mathrm{~kg} / \mathrm{fed}$ of ammonium sulphate $(20.5 \% \mathrm{~N}) 50 \mathrm{~kg}$ which added during soil preparing and the rest $(200 \mathrm{~kg})$ was added in two equal portions, three and five weeks after sowing.

Soil organic matter [town refuse (TR), farmyard manure (FYM) and compost (COM)] with three rates [10, 15 and 20 ton/fed] for each treatment were mixed in $15 \mathrm{~cm}$ soil depth during soil preparing. Each treatment consists of 3 plots, each one was $4 \mathrm{~m}^{2}$. Data of soil analyses according to (Klute, 1986) were tabulated in Table (1). Source of irrigation water used from a well, which has EC, $2.12 \mathrm{dS} / \mathrm{m}$.

\section{Soil physical properties determinations.}

\section{Soil bulk density.}

$\mathrm{Bd}=\mathrm{M} / \mathrm{V}$

where:

$\mathrm{Bd}=$ The soil bulk density $\left(\mathrm{Mg} / \mathrm{m}^{3}\right)$

$\mathrm{M}=$ The mass of soil $(\mathrm{Mg})$

$\mathrm{V}=$ Soil volume $\left(\mathrm{m}^{3}\right)$

Infiltration rate (Philip, 1957).

$\mathrm{D}=\mathrm{S} . \mathrm{t}^{0.5}+\mathrm{At}$

$\mathrm{I}=0.5 \cdot \mathrm{S} \cdot \mathrm{t}^{-0.5}+\mathrm{A}$

where:

$\mathrm{D}=$ Cumulative infiltration depth $(\mathrm{mm})$

$\mathrm{I}=$ Infiltration rate $(\mathrm{mm} / \mathrm{h})$

$\mathrm{t}=$ Time $(\mathrm{h})$

$\mathrm{A}$ and $\mathrm{S}=$ constants.

Water Use Efficiency (Nobel, 1980).

$\mathrm{WUE}=\mathrm{Y} / \mathrm{IR}$

where:

$$
\begin{aligned}
\text { WUE = } & \text { water use efficiency }\left(\mathrm{kg} / \mathrm{m}^{3}\right) \\
\mathrm{Y}= & \text { total crop yield }(\mathrm{kg} / \mathrm{fed}) \\
\mathrm{IR}= & \text { total amount of irrigation water } \\
& \text { applied }\left(\mathrm{m}^{3} / \mathrm{fed}\right) .
\end{aligned}
$$


Table 1. Some physical and chemical properties of surface soil sample

\begin{tabular}{ccccccccc}
\hline $\begin{array}{c}\text { Soil } \\
\text { sample } \\
(\mathbf{c m})\end{array}$ & $\begin{array}{c}\text { Course } \\
\text { sand \% }\end{array}$ & $\begin{array}{c}\text { Fine } \\
\text { sand \% }\end{array}$ & Silt \% & Clay \% & Texture & $\begin{array}{c}\text { Bulk density } \\
\left(\mathbf{M g} / \mathbf{m}^{\mathbf{3}}\right)\end{array}$ & pH & $\begin{array}{c}\text { EC } \\
(\mathbf{d S} / \mathbf{m})\end{array}$ \\
$0-15$ & 15.02 & 77.89 & 4.68 & 2.41 & Sandy & 1.69 & 7.76 & 2.34 \\
\hline
\end{tabular}

\section{The ANN model}

To construct ANN model. First, conceptualize the inputs and outputs to be used. Second, gathering data to be used for training (learning) the model. Third, create the ANN model. Fourth, test the model with some cases. Finally, validate the model or examine how the ANN model performs with the test data. The aim of the learning procedure is to determine the optimal set of weights and biases that produce the correct output for any input. The output of the network is compared with the target response to produce an error. Once the ANN is properly trained, it can be generalized to similar situations that are unprecedented. ANNs usually consist of three layers (input layer, hidden layers, output layer) (Noor et al., 2016). A flowchart of the ANN modeling procedure is shown in Fig. (2).

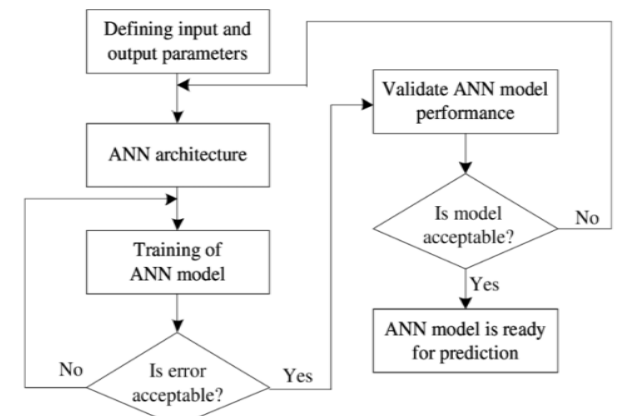

Fig. 2. Neural network modelling procedure flowchart (Noor et al., 2016)

The ANN model backpropagation with two hidden layers were used in this study. This type of ANN is a nonlinear data transformation structure consisting of input and output nodes connected to hidden nodes by adaptable coefficients. The hidden nodes depend on the complexity of the underlying problem and is determined empirically by calibrating ANN with different numbers of hidden nodes. Both the hidden and output nodes contain transfer function of sigmoid that provides the ANN with nonlinear capabilities. The accuracy of the network was evaluated by the RMSE and $\mathrm{R}^{2}$ (Abdullah and Tiong, 2008). $\mathrm{R}^{2}$ is represents the actual data sets, it can vary from 0 to 1 . An $\mathrm{R}^{2}$ value close to 1 indicates that the ANN model perfectly predicts the output.

$\operatorname{RMSE}=\sqrt{\frac{1}{n} \sum_{i=1}^{n}\left(x_{i}-y_{i}\right)^{2}}$

where:

$\mathrm{n}=$ number of data points during testing process

$x_{i}=$ value from measured

$y_{\mathrm{i}}=$ value from predicted

\section{RESULTS AND DISCUSSION}

\section{Soil bulk density (Bd)}

Soil bulk density (Bd) values were decreased as a result for applied different kinds and rates of organic matter (OM) to the soil as illustrated in Table (2). The different $\mathrm{OM}$ reduced the $\mathrm{Bd}$ to $1.57,1.53$ and 1.50 $\mathrm{Mg} / \mathrm{m}^{3}$ with town refuse (TR) treatments, the $\mathrm{Bd}$ reached to $1.46,1.44$ and $1.39 \mathrm{Mg} / \mathrm{m}^{3}$ with $\mathrm{FYM}$ treatments and the $\mathrm{Bd}$ reduced to $1.33,1.32$ and 1.28 $\mathrm{Mg} / \mathrm{m}^{3}$ with compost treatments from $1.5 \mathrm{Mg} / \mathrm{m}^{3}$ measured in control plots under three rates 10,15 and 20 ton/fed respectively. The $\mathrm{Bd}$ decreased under different and rates of $\mathrm{OM}$ is due to a dilution effect resulting from the mixing of the applied OM with the more dense soil mineral fractions (Aranyos et al., 2016). In addition, $\mathrm{OM}$ treatments reduced the $\mathrm{Bd}$ of soil to its least, as it promotes total porosity because bacterial glue acts as soil particle binding agent. These binding agents increasing soil aggregate and cause to decrease soil Bd. Moreover, the reduction in $\mathrm{Bd}$ may be related to the mixing of soil with less dense organic material or by enhancing the fine particle aggregation leading to the higher pore volume in the soil as well as a decreased particle density. Thus increase in applied compost long period may cause a significant decrease in soil bulk density. 
Table 2.Effect of different types and rates of organic matter on some soil physical properties

\begin{tabular}{cccccccc}
\hline Treatment & rate & $\begin{array}{c}\text { Bulk } \\
\text { density } \\
\left(\mathbf{M g} / \mathbf{m}^{\mathbf{3}}\right)\end{array}$ & $\begin{array}{c}\text { Field } \\
\text { capacity } \\
(\mathbf{\%})\end{array}$ & $\begin{array}{c}\text { Wilting } \\
\text { point } \\
(\mathbf{\%})\end{array}$ & $\begin{array}{c}\text { Available } \\
\text { water }(\boldsymbol{\%})\end{array}$ & $\begin{array}{c}\text { Cumulative } \\
\text { infiltration } \\
(\mathbf{m m})\end{array}$ & $\begin{array}{c}\text { Infiltration } \\
\text { rate }(\mathbf{m m} / \mathbf{h})\end{array}$ \\
\hline Control & & 1.67 & 5.64 & 1.02 & 4.62 & 183.96 & 40.84 \\
Town refuse & $\mathbf{1 0}$ & 1.57 & 7.27 & 1.92 & 5.35 & 145.37 & 31.49 \\
$(\mathbf{T R})$ & $\mathbf{1 5}$ & 1.53 & 9.46 & 3.16 & 6.3 & 136.33 & 28.62 \\
Farmyard & $\mathbf{2 0}$ & 1.5 & 11.95 & 4.76 & 7.19 & 128.84 & 25.95 \\
manure & $\mathbf{1 0}$ & 1.46 & 9.11 & 2.72 & 6.39 & 135.21 & 28.39 \\
$(\mathbf{F Y M})$ & $\mathbf{2 0}$ & 1.44 & 11.69 & 4.04 & 7.65 & 110.16 & 23.91 \\
Compost & $\mathbf{1 0}$ & 1.39 & 15.53 & 6.88 & 8.65 & 103.16 & 19.68 \\
$(\mathbf{C O M})$ & $\mathbf{1 5}$ & 1.32 & 13.57 & 4.24 & 9.33 & 96.27 & 22.76 \\
& $\mathbf{2 0}$ & 1.28 & 16.96 & 6.08 & 10.88 & 91.94 & 17.71 \\
\end{tabular}

\section{Soil available water (AW)}

The influenced of addition different organic matter (OM) types on the soil available water (AW), has given in Table (2) and Fig. (3). It is evident that, AW increased with increasing rates of TR, FYM and COM. AW was increased by 14,27 and $36 \%$ with TR treatments, 28, 40 and $47 \%$ with FYM treatments and 50,58 and $64 \%$ with $\mathrm{COM}$ treatments relatively to control under three applications rates 10,15 and 20 ton/fed, respectively. The increased efficiency of water hold capacity at soil field capacity is largely the result of an increase in micro pores. At soil wilting point pores filled with air, and the AW is largely determined by the Specific surface area (SSA) of a soil and the water films thickness on these surfaces. (SSA) of a soil for sandy soils much less than other soils types, in higher tensions, hold much less water. However, with the increase OM addition (SSA) of a soil increases resulting in increased $\mathrm{AW}$ at wilting point. This increase in AW might be attributed to increased number of micro pores and decreased number of macro pores as compared with the control (Wanniarachchi et al. 2019). increase addition of different OM resulted in increased plant AW in soil over control, indicating improvement in soil physical and structure quality.

\section{Infiltration rate $(\mathbf{I})$}

Table (2) and Fig. (3) shows that the addition of TR 10,15 and 20 ton/fed lead to, infiltration rate (I) values decreased to $31.49,28.62$ and $25.95 \mathrm{~mm} / \mathrm{h}$, with reduction of 23,30 and $36 \%$. In addition, (I) values decreased to $28.39,23.91$ and $19.68 \mathrm{~mm} / \mathrm{h}$ with addition of FYM 10, 15 and 20 ton/fed with reduction of 30, 41 and $52 \%$. Also, data referred that (I) decreased to 22.76 , 17.71 and $15.42 \mathrm{~mm} / \mathrm{h}$ by application of COM 10, 15 and $20 \mathrm{ton} / \mathrm{fed}$, with reduction of 44,57 and $62 \%$ as compared with control, respectively. Data in Table (2) showed that the application of TR, FYM and COM in different rates decreased cumulative infiltration compared to control, from $184 \mathrm{~mm}$ in control to $82 \mathrm{~mm}$ in 20 ton/fed COM treatment, this resulted data agreement with (Aranyos et al., 2016). Application of OM greatly decreased the soil ability to conduct water, such effect attributed to the modification of pore size distribution, decreasing the large pores (drainable pores), increasing the fine pores (water retention pores) and consequently decreasing the rate of water movement. The decreasing in cumulative infiltration attributed to the role of $\mathrm{OM}$ in increasing soil aggregate and then decreased the pore space. For OM, the decreasing effect may be attributed to more aggregation of mixed soil then restrict the water flow in soil or due to the increase the fine pores that responsible for decrease in the (I) of treatments compared to control.

\section{Soil productivity and Water use efficiency}

The sandy soil productivity is most limited by their low soil available water (AW), fertility and increased losses of deep percolation. Thus, the management and sustainable of these soil should be achieved by increasing its available water (AW), fertility and reducing losses due to deep percolation by application of organic matter (OM). Data presented in Table (3) illustrated the soil spinach productivity under different addition of OM. The added TR, FYM and COM to the studied sandy soil had effects on soil spinach productivity (Tofah, 2015 and Faiyad et al., 2019). Data in Table (3) and Fig. (4) showed that spinach yield weight in $\mathrm{kg} / \mathrm{fed}$ increased with increasing rates of different $\mathrm{OM}$ applications. The lowest value of productivity was $3105 \mathrm{~kg} / \mathrm{fed}$ of control, meanwhile the highest value was $9878 \mathrm{~kg} / \mathrm{fed}$ of soil treated with COM 20 ton/fed. 


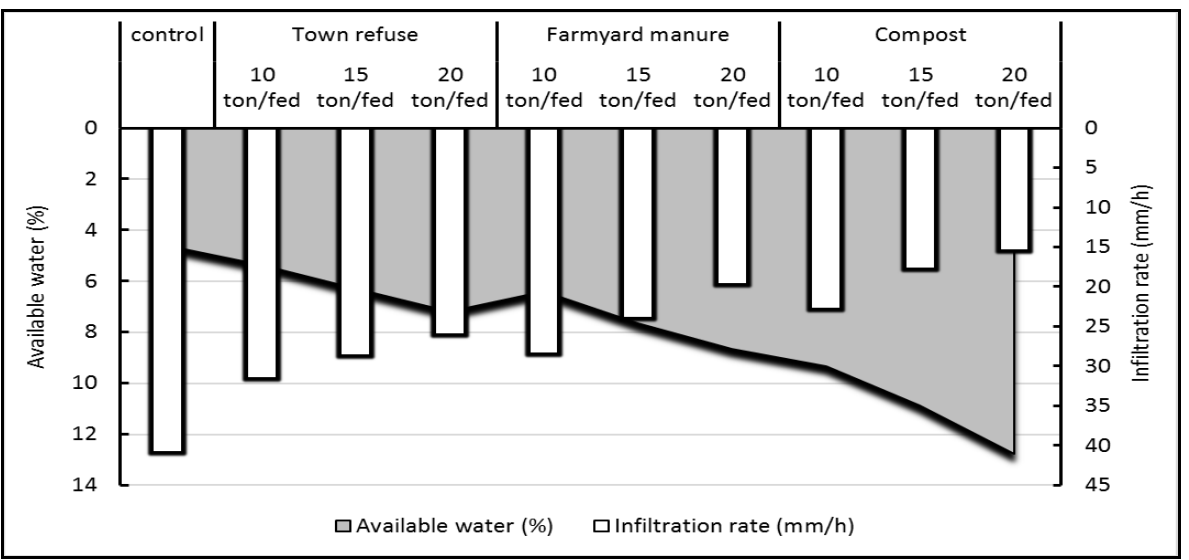

Fig. 3. Effect of different types and rates of organic matter on available water and infiltration rate

Table 3. Effect of different types and rates of organic matter on soil spinach productivity and WUE

\begin{tabular}{cccc}
\hline \multirow{2}{*}{ Treatment } & rate & $\begin{array}{c}\text { Soil spinach productivity } \\
(\mathbf{k g} / \mathbf{f e d})\end{array}$ & WUE $\left(\mathbf{k g} / \mathbf{m}^{\mathbf{3}}\right)$ \\
\hline \multirow{2}{*}{ Control } & & 3105 & 1.74 \\
& $\mathbf{1 0}$ & 3747 & 2.10 \\
Town refuse & $\mathbf{1 5}$ & 4402 & 2.46 \\
& $\mathbf{2 0}$ & 4919 & 2.75 \\
Farmyard manure & $\mathbf{1 0}$ & 4518 & 2.53 \\
& $\mathbf{1 5}$ & 5483 & 3.07 \\
& $\mathbf{2 0}$ & 6084 & 3.40 \\
Compost & $\mathbf{1 0}$ & 6556 & 3.67 \\
& $\mathbf{1 5}$ & 7781 & 4.35 \\
& $\mathbf{2 0}$ & 9878 & 5.52 \\
\hline
\end{tabular}

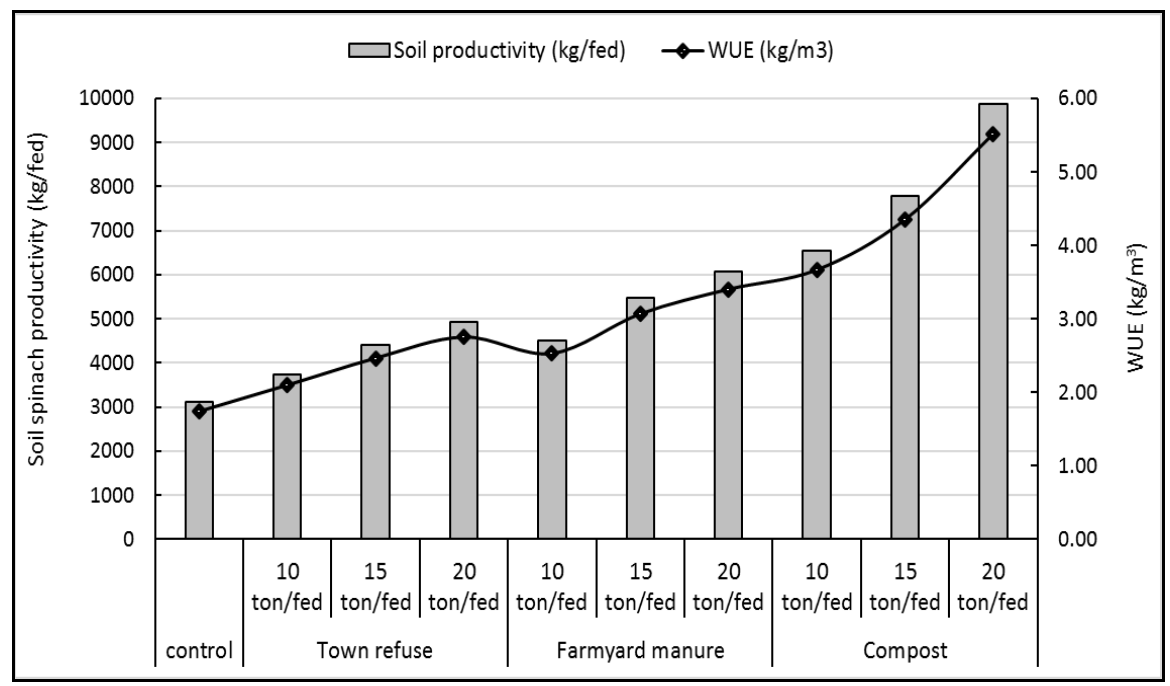

Fig. 4. Effect of different types and rates of organic matter on soil spinach productivity and WUE 
Values of the water use efficiency (WUE), which reflect the relation between the production and the total seasonal water used are presented in Table (3) and Fig. (4). Data show that treating sandy soil with tested OM led to an increase in WUE by spinach yield in $\mathrm{kg}$ per each cubic meter of irrigation water used. Addition of TR, FYM and COM had a superior effect on WUE of spinach yield. The WUE values under TR treatments were $2.10,2.46$ and $2.75 \mathrm{~kg} / \mathrm{m}^{3}$, with increasing rate to 17, 29 and 37\%. In addition, WUE values under FYM treatments were $2.53,3.07$ and $3.40 \mathrm{~kg} / \mathrm{m}^{3}$, with increasing rate to 31,43 and $49 \%$. Also, data referred that WUE values under COM treatments were 3.67, 4.35 and $5.52 \mathrm{~kg} / \mathrm{m}^{3}$, with increasing rate to 53,60 and $68 \%$ as compared to control under 10, 15 and 20 ton/fed respectively. OM can indirectly improve soil structure by increasing microbial activity and thus production of microbial slimes, fungal hyphae and/or roots bind aggregates together. $\mathrm{OM}$ is a significantly nutrients reservoir and can retain nutrients to plants in available form (Pragna et al., 2017). Other beneficial effects of OM include increasing plant water availability, decreasing leaching of nutrients, reducing erosion and evaporation and prevention of plants diseases. Further, OM can act as a long-term slow release for fertilizer and provide spinach yield by their needs of irrigation water without any stress.

\section{ANN model}

The data (891 observations) from literature were separated into two groups. $75 \%$ of the data $(668$ observations) were set for training, and $25 \%$ (223 observations) for testing. Statistical measures for the entire collected dataset are presented in Table (4). The inputs were [sand $(\mathrm{S})$, silt $(\mathrm{Si})$, clay $(\mathrm{C})$, town refuse (TR), farmyard manure (FYM), compost (COM), Electrical conductivity of irrigation water (EC), irrigation water applied (IR)] for prediction of [soil bulk density (Bd), available water (AW), infiltration rate (I), soil spinach productivity (Pro) and water use efficiency (WUE)]. The data used in this study Table (4) has a wide range of soil particle size distribution, with sand content ranging from 66.39 to $95.62 \%$, silt content ranging from 2.52 to $19.72 \%$ and clay content ranging from 1.37 to $16.50 \%$. Also, differ in the kind of organic matter addition [TR, FYM, COM] and differ rates ranging from 0 to 20 ton/fed. EC of irrigation water (EC) ranging from 1.33 to $4.42 \mathrm{dS} / \mathrm{m}$. Irrigation water applied (IR) ranging from 1698 to $1867 \mathrm{~m}^{3} / \mathrm{fed}$.

Several ANN models were trained with various design parameters including number of hidden layers and number of nodes in each hidden layer. The selection of the optimum model was based on minimizing the difference between the ANN predicted and measured values outputs Fig (5).

The best model consisted of hidden layers with 10 and 20 nodes in the first and second hidden layer. The architecture of the developed ANN model is depicted in Fig.(6).

The RMSE decreased with increasing of learning iterations for 5 outputs. The training network gave achieved the best results at 100,000 training runs with RMSE at 0.0298 and $\mathrm{R}^{2}$ at 0.9879 Fig.(5). Also the ANN model was tested with testing data set (223 observations) where RMSE and $\mathrm{R}^{2}$ equals 0.0335 and 0.9830 respectively. According to these results, outcomes were acceptable during the training and testing stages. After network training and optimization, we carried out the verification stage for the optimized network. This was conducted through the comparison between the measured values (Data that an ANN model has never seen before) from field experimental and the predicted values from ANN model, and the results are shown in Figs. (7-11).

Table 4. Statistical measures for the entire collected dataset

\begin{tabular}{ccccc}
\hline Parameter & Minimum & Maximum & Mean & Standard deviation \\
\hline Sand (\%) & 66.39 & 95.62 & 85.49 & 9.64 \\
Silt (\%) & 2.52 & 19.72 & 8.43 & 5.08 \\
Clay (\%) & 1.37 & 16.50 & 6.07 & 4.72 \\
Town refuse (ton/fed) & 0 & 20 & 5 & 7.46 \\
Farmyard manure (ton/fed) & 0 & 20 & 5 & 7.46 \\
Compost (ton/fed) & 0 & 20 & 5 & 7.46 \\
EC of irrigation water (dS/m) & 1.33 & 4.42 & 2.74 & 0.65 \\
Irrigation water applied (m/fed) & 1698 & 1867 & 1792 & 35.96 \\
\hline
\end{tabular}




\begin{tabular}{|c|c|c|c|}
\hline \multicolumn{4}{|c|}{ 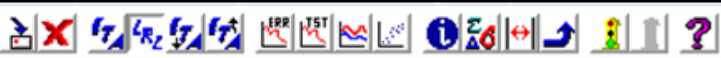 } \\
\hline \multicolumn{2}{|l|}{ Network Definition } & \multicolumn{2}{|l|}{ Training Controls } \\
\hline \multicolumn{2}{|c|}{ Predicting soil productivity } & \multirow{12}{*}{$\begin{array}{l}\text { Max Iterations: } \\
\text { Learn Control Start: } \\
\text { Learn Rate: } \\
\text { Learn Rate Max: } \\
\text { Learn Rate Min: } \\
\text { Momentum: } \\
\text { Patterns per Update: } \\
\text { FAST-Prop: } \\
\text { Screen Update: } \\
\text { AutoSave Rate: } \\
\text { Tolerance: } \\
\text { Quit at RMS Error: }\end{array}$} & 100000 \\
\hline Network Layers: & 4 & & 10001 \\
\hline Input Nodes: & 8 & & 0.003620 \\
\hline Output Nodes: & 5 & & 0.150500 \\
\hline Hidden Nodes: & 30 & & 0.001000 \\
\hline Transfer Functions: & Sigmoid & & 0.800 \\
\hline Connections: & 380 & & 668 \\
\hline Training Patterns: & 668 & & 0.000 \\
\hline Test Patterns: & 223 & & 5 \\
\hline Network Size (Bytes): & 204202 & & 500 \\
\hline Training Mode: & standard & & 0.00000 \\
\hline Net Training/Totat: & $1 / 0$ & & 0.00000 \\
\hline \multicolumn{4}{|l|}{ Training Results } \\
\hline Iteration: & 100000 & Training Speed (CPS): & $22193 \mathrm{~K}$ \\
\hline \multirow[t]{2}{*}{ Percent Complete: } & $100.0 \%$ & Time Remaining: & $0: 0: 0$ \\
\hline & RMS Error & Correlation Tol. Correct & \\
\hline Training Set: & 0.029832 & 0.987984 & \\
\hline Test Set: & 0.033581 & 0.983012 & \\
\hline
\end{tabular}

Fig. 5. Network definition for ANN model

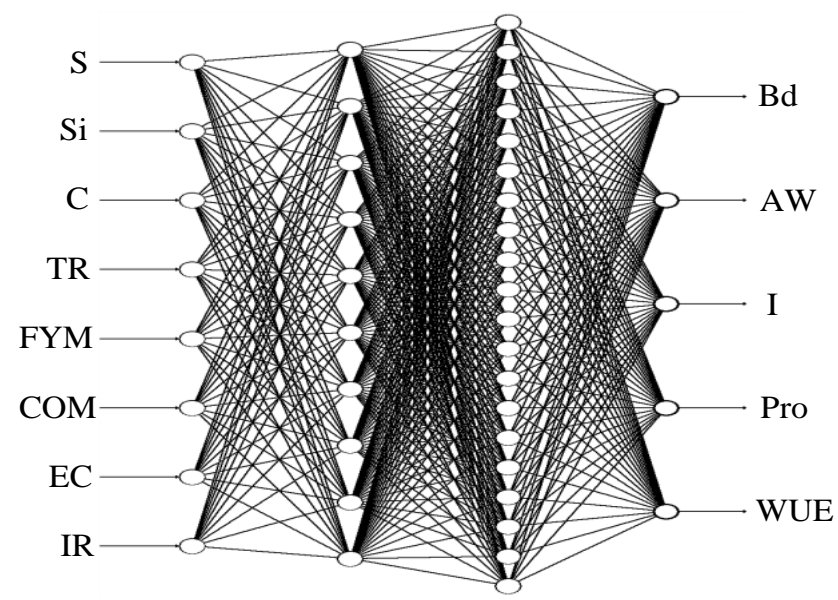

Fig. 6. The architecture of the developed ANN model

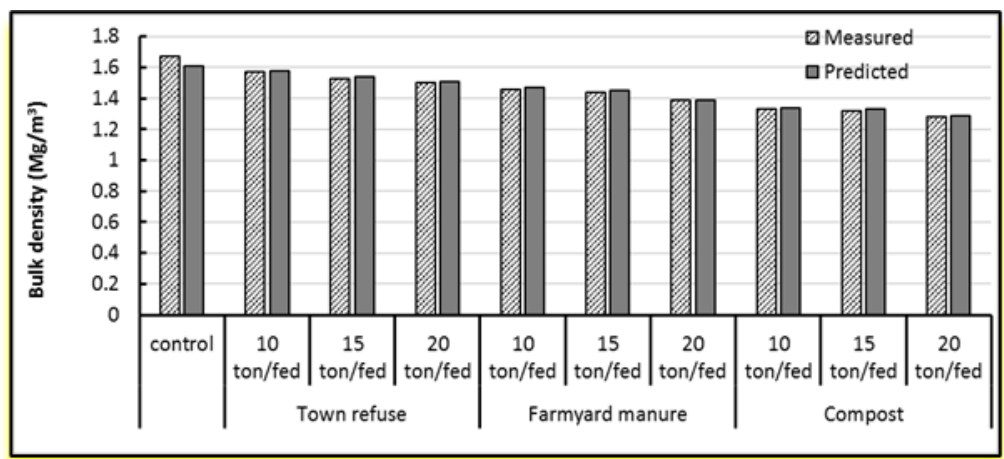

Fig. 7. Measured and predicted ANN model for bulk density under different treatments 


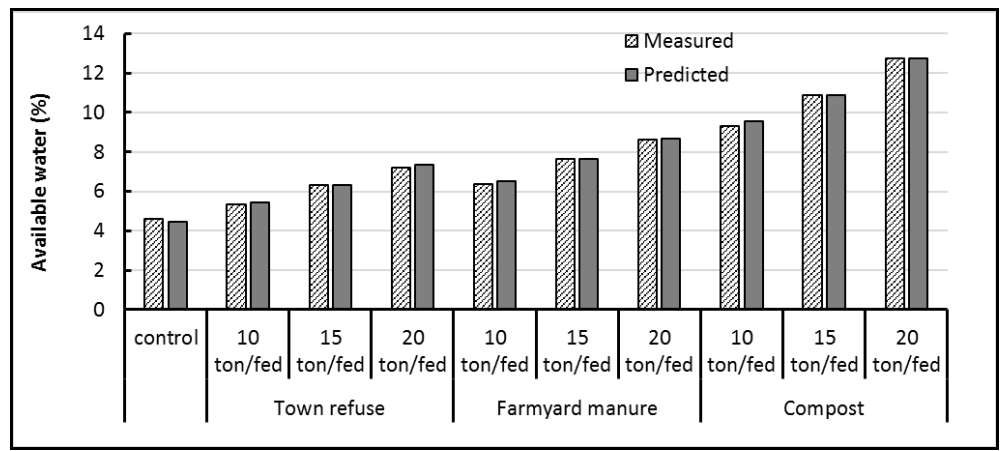

Fig. 8. Measured and predicted ANN model for available water under different treatments

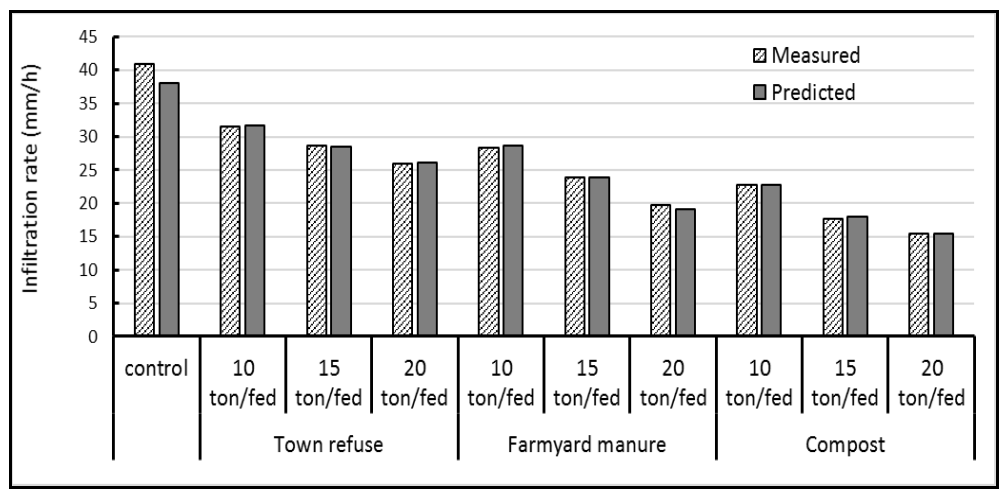

Fig. 9. Measured and predicted ANN model for infiltration rate under different treatments

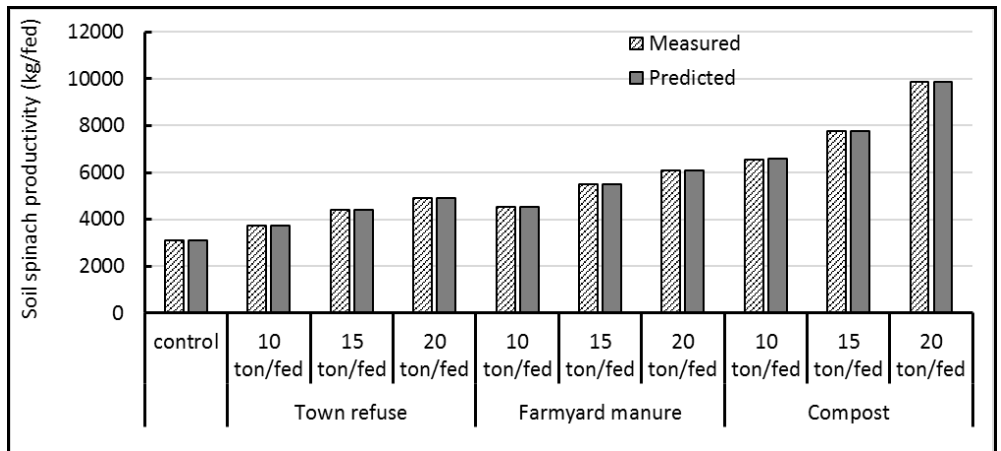

Fig. 10. Measured and predicted ANN model for soil spinach productivity under different treatments

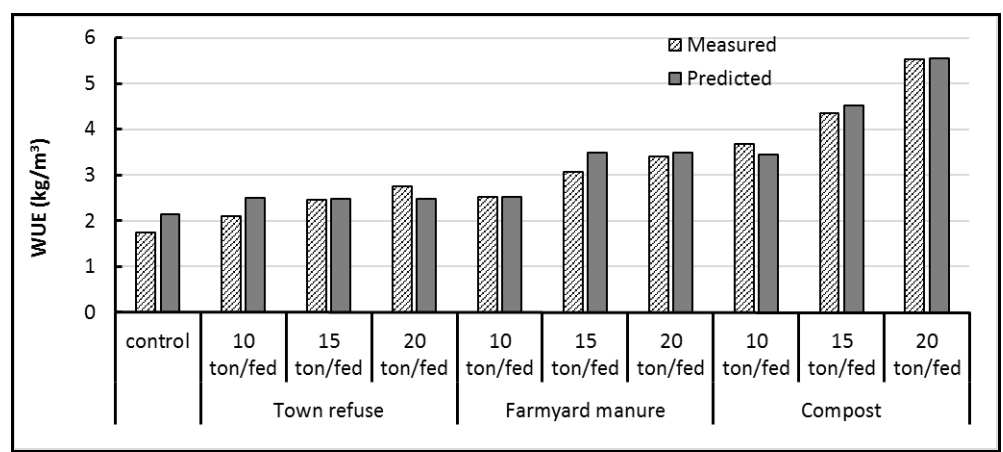

Fig. 11. Measured and predicted ANN model for WUE under different treatments 
Table 5. The ANN model recall statistical

\begin{tabular}{cccc}
\hline parameter & RMSE & Maximum Error & $\begin{array}{c}\text { Correlation } \\
\text { Coefficient } \\
\left(\mathbf{R}^{\mathbf{2}}\right)\end{array}$ \\
\hline Bulk density $\left(\mathbf{g} / \mathbf{c m}^{\mathbf{3}}\right)$ & 0.00909 & 0.01416 & 0.99955 \\
Available water $\mathbf{( \% )}$ & 0.10528 & 0.22275 & 0.99947 \\
Infiltration rate $(\mathbf{m m} / \mathbf{h})$ & 0.23878 & 0.58931 & 0.99902 \\
Soil spinach productivity $\mathbf{( k g} / \mathbf{f e d})$ & 14.28973 & 34.96143 & 0.99998 \\
WUE $\left(\mathbf{k g} / \mathbf{m}^{\mathbf{3}}\right)$ & 0.26762 & 0.49729 & 0.96883 \\
\hline
\end{tabular}

From Table (5) the RMSE between measured and predicted for Bd, AW, I, Pro and WUE were 0.00909 $\mathrm{Mg} / \mathrm{m}^{3}, 0.10528 \%, 0.23878 \mathrm{~mm} / \mathrm{h}, 14.28973 \mathrm{~kg} / \mathrm{fed}$ and $0.26762 \mathrm{~kg} / \mathrm{m}^{3}$. While the $\mathrm{R}^{2}$ were equal to 0.99955 , $0.99947,0.99902,0.99998$ and 0.96883 respectively (Warmling et al., 2019 and Al-Janobi et al., 2020). The high correlation coefficient for outputs parameters recall indicated for excellent prediction of ANN model for data has never seen before.

\section{CONCLUSION}

In this study, ANN model was developed to predict some soil physical properties [soil bulk density, available water, infiltration rate], soil productivity and water use efficiency under three different kinds of organic matter [town refuse, farmyard manure and compost] with three rates [10, 15 and 20 ton/fed] for each treatment. The ANN model inputs were [sand, silt, clay, town refuse, farmyard manure, compost, Ec of irrigation water, irrigation applied water]. The architecture of optimal ANN model consisted of two hidden layers with 10 and 20 nodes in the first and the second hidden layers respectively. After network training and optimization, we carried out the verification stage for the optimized network. This was conducted through the comparison between the measured values (Data that an ANN model has never seen before) from field experimental and the predicted values from ANN model. the RMSE between measured and predicted for soil bulk density, available water, infiltration rate, soil productivity and water use efficiency were 0.00909 $\mathrm{Mg} / \mathrm{m}^{3}, 0.10528 \%, 0.23878 \mathrm{~mm} / \mathrm{h}, 14.28973 \mathrm{~kg} / \mathrm{fed}$ and $0.26762 \mathrm{~kg} / \mathrm{m}^{3}$. While the $\mathrm{R}^{2}$ were equal to 0.99955 , $0.99947,0.99902,0.99998$ and 0.96883 respectively. The high correlation coefficient for parameters outputs recall indicate for excellent prediction of ANN model for data has never seen before.

\section{REFERENCES}

Abdullah, S. and E. C. Tiong. 2008. Prediction of palm oil properties using artificial neural network. Inter. J. of Com. Sci. and Net. Sec., 8 (8): 101-106.

Aboukarima, A.M. 2007. Draft models of chisel plow based on simulation using artificial neural networks. Misr J. Ag. Eng., 24(1): 42-61.
Aboukarima, A. M. and A. F. Saad. 2006. Assessment of different indices depicting soil texture for predicting chisel plow draft using neural networks. Alex. Sci. Exch. J., 27 (2): 170-180.

Aboukarima, A.M., M.N. El Awady, A.G. El-Kabany and M.H. Kabeel. 2004. Predicting unit draft of tillage implements using statistical models and neural networks. The $12^{\text {th }}$ Conf. of Misr Soc. of Ag. Eng., 21(4): 239-249.

Akbarzadeh, A., R.T. Mehrjardi, H. Rouhipour, M. Gorji and H.G. Refahi. 2009. Estimating of soil erosion covered with rolled erosion control systems using rainfall simulator (Neuro-fuzzy and Artificial Neural Network Approaches). J. of Ap. Sci. Res., 5(5): 505-514.

Al-Janobi, A., S. Al-Hamed, A. Aboukarima and Y. Almajhadi. 2020. Modeling of draft and energy requirements of a moldboard plow using artificial neural networks based on two novel variables. Engenharia Agrícola 40 (3): 363-373.

Aranyos, J. T., A. Tomócsik,M. Makádi, J. Mészáros and L. Blaskó. 2016. Changes in physical properties of sandy soil after long-term compost treatment. International Agrophysics (30): 269-274.

Aru, O. E. and M. Okpara. 2018. Review of artificial neural network: an emerging problem solving tool in computing. American Journal of Engineering Research, 7 (5): 152161.

El Awady, M.N., A.G. El-Kabany, M.H. Kabeel and A.M. Aboukarima. 2003. Plows performance under Egyptian conditions depicted by artificial neural networks. The $11^{\text {th }}$ Conf. of Misr Soc. of Ag. Eng., 20(4): 919-936.

Faiyad, R. M., G. B. Ahmed and R. El-Mahdy. 2019. Maximizing Utilization of Some Organic Fertilizers to Produce the Highest Yield of Cowpea. Egypt. J. Soil. Sci. 59 (1): 53-66.

Gholami, V., M.J. Booij, E.N. Tehrani and M.A. Hadian. 2018. Spatial soil erosion estimation using an artificial neural network (ANN) and field plot data. CATENA (163): 210-218.

Klute, A. 1986. Methods of soil analysis. Part 1. Physical and microbiological methods. $2^{\text {nd }}$ edition. Agronomy. Monogr. 9. ASA, Madison, WI. USA, pp: 228-235.

Nobel, P.S. 1980. Leaf anatomy and water use efficiency. In: Turner NC, Kramer PJ (eds) Adaptation of plants to water and high temperature stress. Wiley Interscience, New York, pp: 43-55. 
Noor, C.W.M., R. Mamat; G. Najafi, M.H.M. Yasin, C.K. Ihsan and M.M. Noor. 2016. Prediction of marine diesel engine performance by using artificial neural network model. J. of Mechanical Eng. and Sci., 10 (1):1917-1930.

Philip, J.R. 1957. The theory of infiltration. 1- The infiltration equation and its solution. Soil Sci., 83: 345-357.

Pragna, G., M. Jyothi, N. Kunari and I.B. Rao. 2017. The effect of different soil amendment on irrigation frequency, crop yield, water use efficiency of Spinach. International Journal of Applied Biology and Pharmaceutical Technology 8(1): 12-18.

Sorour, H.M. 2006. Prediction of wheat deterioration during storage period using artificial neural network. Misr J. Ag. Eng., 23(3): 637-657.
Tofah, R. 2015. Effect of organic manure kinds on growth, yield and quality of Spinach plant. Tishreen University Journal for Research and Scientific Studies-Biological Sciences 37 (2): 279-291.

Wanniarachchi D., M. Cheema, R. Thomas, V. Kavanagh and L. Galagedara. 2019. Impact of soil amendments on the hydraulic conductivity of boreal agricultural podzols. Agriculture 9 (6): 133-144.

Warmling, M., R. Mendes, J. Albuquerque and D. Bortolini. 2019. Artificial neural networks to predict soil water retention of Santa Catarina - Brazil. In book: Terra Mudanças Climáticas e Biodiversidade, Publisher: Barlavento, pp: 393-403. 


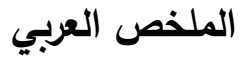

\section{التنبؤ بانتاجية التربة نتيجة اضافة المواد العضوية باستخدام الثبكات العصبية}

$$
\text { ضياء سعيد منير بولس }
$$

معدل الرشـح، انتاجيـة التربـة مـن السبانخ، كفـاءة استخدام المياه). تم التحقق من كفاءة الثبكة العصبية الاصطناعية

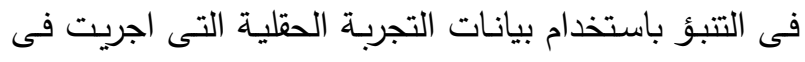
منطقة السادات بمحافظة المنوفية (بيانات لم يسبق للشبكة العصبية الاصطناعية التعرض لها من قبل) وذلك باستخدام

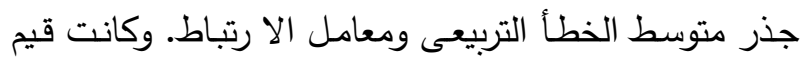
جذر متوسط الخطأ التربيعى بين القيم الدقاسة من التجربة الحقلية والقيم الهتنبأ بها من الثبكة العصبية الاصطناعية

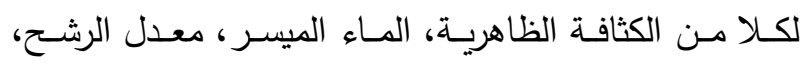

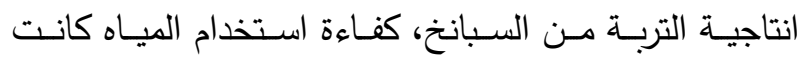

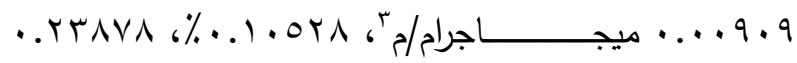

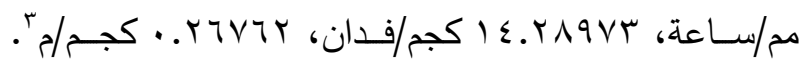

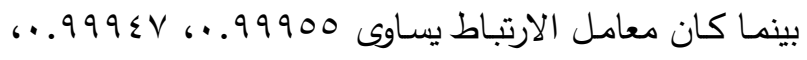

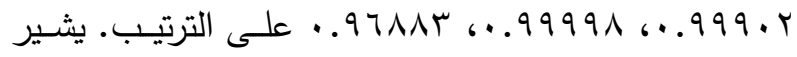
معامل الارتباط المرتفع للمخرجات الى التتبؤ المتاز للشبكة

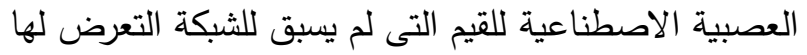

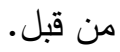

أستخدام نموذج الشبكات العصبية الاصطناعية (ANN) للتتبؤ ببعض خواص التربة الطبيعية (الكثافة الظاهرية، الماء

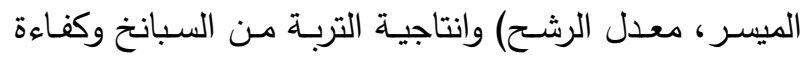

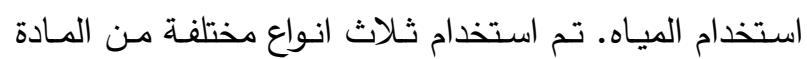
العضـوية (مخلفـات المـدن، مخلفـات المزرعـة، الكمبوست

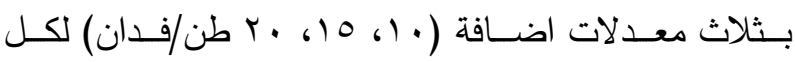
معاملـة. استخدمت الشبكة العصبية الاصـطناعية متعددة الطبقات ذات التغذية الامامية حيث تتكون من ^ عصبونات

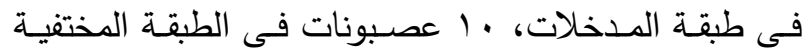

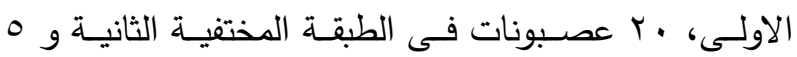
عصبونات فى طبقة المخرجات وتم تدريبها بطريقة التعليم

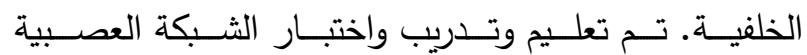
الاصطناعية بمشاهدات من الدرسات السابقة (17) مشاهدة للتدريب و rr r مشاهدة للاختبار). كانت الدحخلات للشبكة العصبية الاصطناعية هى (نسبة الرمل، نسبة السلت، نسبة الطين، مخلفات المدن، مخلفات المزرعة، الكمبوست، ملوحة مياه الرى، كمية المياه المضـافة). وكانت مخرجات الشبكة الثيأ العصبية الاصطناعية هى (الكثافة الظاهرية، الماء الميسر ، كاتهات 